\title{
Review of Methodological Approaches to Human Milk Small Extracellular Vesicle Proteomics
}

\author{
Brett Vahkal ${ }^{1}$, Jamie Kraft ${ }^{2}$, Emanuela Ferretti ${ }^{3}(\mathbb{D})$, Minyoung Chung ${ }^{4}$, Jean-François Beaulieu ${ }^{5}$ (D) and \\ Illimar Altosaar 1,*(D)
}

1 Department of Biochemistry, Microbiology and Immunology, University of Ottawa, Ottawa, ON K1H 8L1, Canada; bvahkal@uottawa.ca

2 Department of Molecular and Clinical Medicine, University of Gothenburg, SU Sahlgrenska, 41345 Gothenburg, Sweden; jamie.kraft@wlab.gu.se

3 Division of Neonatology, Department of Pediatrics, Children's Hospital of Eastern Ontario, Ottawa, ON K1H 8L1, Canada; eferretti@toh.ca

4 Department of Molecular Genetics, University of Toronto, Toronto, ON M5S 1A8, Canada; minyoung.chung515@gmail.com

5 Department of Immunology and Cell Biology, Université de Sherbrooke, Sherbrooke, QC J1E 4K8, Canada; jean-Francois.Beaulieu@USherbrooke.ca

* Correspondence: altosaar@uottawa.ca

Citation: Vahkal, B.; Kraft, J.; Ferretti,

E.; Chung, M.; Beaulieu, J.-F.;

Altosaar, I. Review of Methodological Approaches to Human Milk Small Extracellular Vesicle Proteomics. Biomolecules 2021, 11, 833. https:// doi.org/10.3390/biom11060833

Academic Editor: Tamás Röszer

Received: 1 May 2021

Accepted: 29 May 2021

Published: 3 June 2021

Publisher's Note: MDPI stays neutral with regard to jurisdictional claims in published maps and institutional affiliations.

Copyright: (C) 2021 by the authors Licensee MDPI, Basel, Switzerland. This article is an open access article distributed under the terms and conditions of the Creative Commons Attribution (CC BY) license (https:// creativecommons.org/licenses/by/ $4.0 /)$.

\begin{abstract}
Proteomics can map extracellular vesicles (EVs), including exosomes, across disease states between organisms and cell types. Due to the diverse origin and cargo of EVs, tailoring methodological and analytical techniques can support the reproducibility of results. Proteomics scans are sensitive to in-sample contaminants, which can be retained during EV isolation procedures. Contaminants can also arise from the biological origin of exosomes, such as the lipid-rich environment in human milk. Human milk (HM) EVs and exosomes are emerging as a research interest in health and disease, though the experimental characterization and functional assays remain varied. Past studies of HM EV proteomes have used data-dependent acquisition methods for protein detection, however, improvements in data independent acquisition could allow for previously undetected EV proteins to be identified by mass spectrometry. Depending on the research question, only a specific population of proteins can be compared and measured using isotope and other labelling techniques. In this review, we summarize published HM EV proteomics protocols and suggest a methodological workflow with the end-goal of effective and reproducible analysis of human milk EV proteomes.
\end{abstract}

Keywords: extracellular vesicles; exosomes; human milk; mass spectrometry; proteomics

\section{Introduction}

Human milk (HM) is the optimal nutrient source to promote growth of infant via a wide range of macro- and micronutrients [1-7]. Characterization of the HM proteome has contributed greatly to our understanding of the dynamic fluid and its wide range of additional biological properties. The bioactive components of HM can facilitate antimicrobial protection and immune modulation through secretory antibodies, oligosaccharides, lactoferrin, cytokines, proteins, and the recently characterized-extracellular vesicles (EVs) [2,8-11].

Formula milk feeding is necessary in situations where HM may not always be available, such as in neonatal intensive care units [12,13]. Significantly, formula milk is deficient in several of the bioactive components found in HM [14,15], including lipids [16]. For example, alkylglycerol-type ether lipids are absent in formula milk but are important in the development of healthy adipose tissue via immune-metabolic signaling [17]. MicroRNAs are also lacking in formula milk [18-22], which are an abundant cargo of HM EVs with an increasingly evident role in infant immune development [23-25]. Notably, vesicles 
detected in formula milk appear to not have EV markers, and are compromised morphologically [22,26], wherein casein micelles have been identified within the population instead [22]. Thus, intact EVs are an important component of HM. The identification of immunomodulatory proteins in HM EVs [11] indicate that further proteomics analyses and characterization of EVs can inform on components to include in formula to help infants thrive [27-32].

The proposed mediators for downstream bioactivity, HM EVs are surrounded by a lipid bilayer, secreted by nearly all cells, and found across biological material [11,33-36]. They contain proteins, RNA and DNA, which can convey cell-to-cell signaling [37,38]. Among the subclasses of EVs are microvesicles and exosomes [39], with distinct surface markers [39,40]. As a subset of EVs, exosomes were first described in 1983 [41,42], but characterized in 2016 by Kowal et al. with surface markers of CD9, CD63 and CD81 [43]. They are considered among a small class of EVs, ranging in size from 20-200 nm [36,44]. Due to limitations in EV isolation procedures, the denotation of "exosomes" to a heterogenous EV population obtained from biofluids has recently been discouraged. This update has been extensively covered in the current guideline for EV research (MISEV 2018) [45]. In this review, we use the term "EVs" or "small EVs", in alignment with MISEV standards [45], to encompass proteomic studies of HM vesicles, where isolation method yielded a population in the average size of $<200 \mathrm{~nm}$.

EVs are proposed to convey signals systemically and between cells [46-48]. In a mouse study, fluorescently labeled bovine milk EV miRs were bioavailable following oral intake and distributed to intestinal mucosa, spleen, liver, heart and brain [46]. On a cellular level, EVs from milk have been shown to enter intestinal cells [23,49], macrophages [50,51], peripheral blood mononuclear cells [52], and vascular endothelial cells [53]. Indeed, HM EVs can withstand digestion, indicating delivery of bioactive cargo to the infant gut lumen $[54,55]$.

Relevant for infant health, functional studies have demonstrated that HM EVs significantly increase cell proliferation [56-58]. Three independent studies of rat necrotizing enterocolitis (NEC), an inflammatory gut disease, showed reduction in NEC severity following feeding or IP administration of HM EVs in vivo [30,31,56]. In a gingival epithelial cell line, re-epithelization of cells in the presence of HM EVs was shown to be p38 MAPKdependent, and cell adhesion molecules E-cadherin and EPCAM were downregulated [59]. In immune regulation, CD4 + T-cell activation and regulatory T-cell induction are inhibited in response to treatment with HM EVs [59]. Treatment also dampened agonist-induced response of toll-like receptors (TLR) 3 and 9, pro-inflammatory cytokines IL-6 and CXCL8 were downregulated [59]. In peripheral blood mononuclear cells, treatment with HM EVs inhibited release of IL-2, IFN $\gamma, \mathrm{TNF} \alpha$, and promoted production of IL-5 [11].

Despite emerging functional data, much of our current understanding of pathways affected by HM cargo is reliant on big data sets derived from "EV-omics", including proteomics [36]. At this point, we note that current proteomics is evolving in a direction of increased effectiveness of methods through miniaturization [60-63] and automation [64]. In addition to advancing the field of single-cell and spatial proteomics, sample preparation time, sample quantity and reagents are also reduced, and peptide analysis is faster $[62,64,65]$. Here, we suggest the use of nano-liquid chromatography and tandem mass spectrometry for reliable HM EV proteomics, which utilizes several of the aforementioned improvements in proteomics workflow [62,66].

$\mathrm{HM}$ is a complicated fluid, which extends to its EV cargo. EV isolation and proteomics methods are ever evolving to further distinguish EV populations and signatures from originating cells [67]. Existing literature is exploring this in plasma and cell-culture derived EVs, which can also inform the future studies of HM EVs. The use of proteomics can reveal functional data related to identified proteins using large-scale analyses, wherein complex molecular mechanisms and pathways are an important focus. In functional analyses, understanding the effects of HM EV treatment is enriched by pathway analyses of omics cargo to postulate signaling pathways that lead to the observed effect. Several studies have 
utilized this approach thus far $[11,56,59]$, which can be helpful for additional verification experiments, future directions.

The diverse approaches and areas of HM EV study have led to the expansion of the field, where a five-fold increase is seen in the last eight years in publications with the title "exosom * or vesicle *", though publications on HM exclusively are in the minority (Figure 1A, Web of Science analytics, 21 April 2021). An upward trend is observed in published works on milk EVs, exosomes, and their investigation using mass spectrometry, however, only a quarter of those studies examine HM (Figure 1B). In this review, we summarize existing literature on HM EV proteomics and suggest a reliable method for EV protein isolation, peptide preparation, detection and bioinformatic annotation. We include alternative methods from EV studies of other biofluids, which may enhance the functional interpretation of $\mathrm{HM} \mathrm{EV}$ proteome.
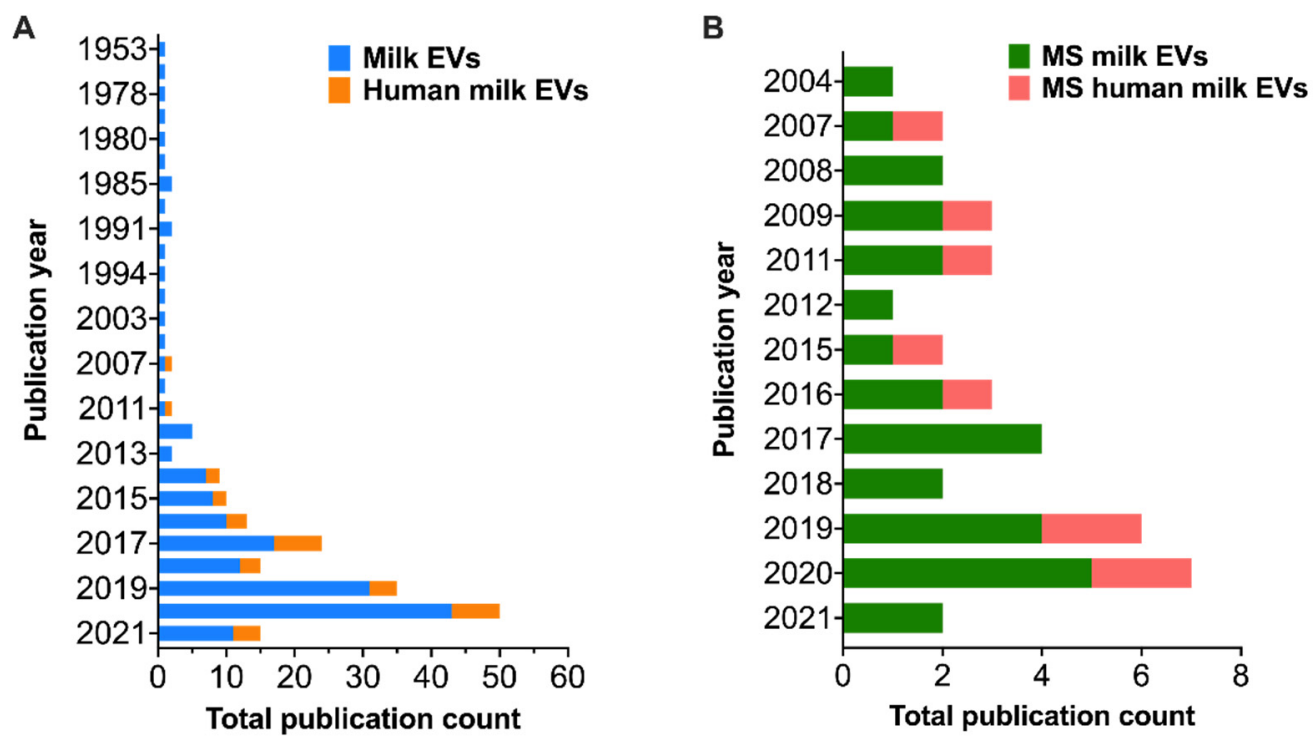

Figure 1. Publication history for extracellular vesicles (EVs) and exosomes. (A) Publication count by year for EVs and exosomes in milk (blue) and human milk (orange), where analyses of vesicles in human milk first appear in 2007. (B) Publication count by year for mass spectrometry analyses of EVs and exosomes in milk (green) and human milk (pink), where mass spectrometry (MS) analysis of milk vesicles first appeared in 2004. Image generated using Prism 9, data provided by search in Web of Science with combination of terms exosome *, vesicle *, milk, human milk, mass spectrometry, including search constraints of title (A) and abstract (B), and document type refined by article and review (accessed 21 April 2021).

\section{Human Milk Small Extracellular Vesicle Isolation}

$\mathrm{HM}$ is a biofluid unique in its composition, with a high concentration of proteins and lipids [68]. Therefore, considerations must be taken in EV isolation to separate the contaminants prior to omics analyses. The experiments conducted on HM EVs vary in their approaches of sample preparation for proteomic or other experimental analyses (Table 1). For the majority of HM EV isolations, a series of differential and ultra-centrifugation steps are conducted to pellet small EVs or exosomes [28,56,69-71]. Several published protocols have combined differential centrifugation with a sucrose gradient [11,72-74]. While centrifugation and gradient isolation techniques can be considered the classic approaches, they are time-consuming and have multiple experimental steps [36]. To make EV isolation technically more accessible, alternative isolation methods are emerging. Size exclusion chromatography columns (e.g., qEV) [75] can yield EVs of superior purity and is increasingly used in the field of non-HM EV isolations [76-80]. Kits (e.g., ExoQuick-TC, PureExo) and precipitation solutions (e.g., total exosome isolation reagent) can provide rapid EV isolation, but result in a higher concentration of contaminants $[78,81]$. Newer approaches in the 
field include asymmetric tangential flow filtration, including asymmetrical flow field flow fractionation (AF4), ion-exchange, electrophoresis and dielectrophoresis, for an advanced separation of vesicles $[67,78]$. AF4, for example, can provide rapid separation of vesicles in up to $1 \mathrm{~nm}$ increments [82], but can have a reduced overall yield [67]. Combinations of the above methods are also proving useful in enriching EV populations from complex biofluids, such as dual-mode chromatography (DMC), which has been tested in plasma to remove contaminating lipoprotein particles [83].

Though promising, several of these methods have not yet been established for separation of lipid and protein content when processing HM samples, wherein differential centrifugation of sample may still be necessary to reach desired purity of EVs from milk [75]. The commonly used and established protocol remains a series of differential centrifugations of $\mathrm{HM}$ to remove fat and cellular debris, and ultra-centrifugation of the resulting supernatant twice at $100,000 \times \mathrm{g}$ for $1.5 \mathrm{~h}$ at $4{ }^{\circ} \mathrm{C}$ to obtain a pellet of small EVs $[28,56,69-71,75]$. Methods such as DMC may prove useful in future isolations of HM EVs, especially when combined with differential centrifugation for obtaining a skim milk sample for further processing. Similarly, SEC could be applied instead of ultra-centrifugation to increase the purity of obtained EV sample. However, these approaches need to be validated in HM biofluid prior to use, where it would be informative to compare EV integrity, yield, sample purity to the classical differential and ultra-centrifugation method.

A question whether the HM protein and lipid contents are sufficiently removed from EVs, remains. Biological variations exist between mammals, where elephant seal milk contains over $50 \%$ fat [84], bovine milk has roughly $4.2 \%$ fat [85], and human milk has varying concentrations between 3-5\% [86]. Additional contaminants in milk are casein and whey proteins [87], wherein casein is present at a higher concentration in bovine milk versus HM (3-5 versus $26 \mathrm{~g} / \mathrm{L}$ ) [68]. Previous proteomics studies from HM EVs have not reported significant interruptions in proteomics analyses from casein and whey, though it may be a consideration for functional analyses. Following isolation, specific clean-up steps should therefore be taken to ensure sensitive and accurate mass spectrometry analyses. These purification steps can include precipitation, which can utilize acetone or methanol among other reagents, or extraction of the protein using solid phase (e.g., C18) and can remove impurities prior to sample digestion [88].

Prior to further sample preparation for proteomics, it is essential to confirm presence, size distribution and concentration of EVs in purified sample [45]. This should include confirmation of surface markers $[39,45]$. For small EV populations, they should include CD9/63/81, and/or Annexin A1 [39,45]. Relying on morphology, scanning electron microscopy can be used to identify size and distribution of EVs. Nanoparticle tracking analysis can be used to map vesicle sizes in a sample and to confirm presence of 20-200 nm vesicles $[35,39,70,89,90]$.

Table 1. Summary of experimental approaches for small extracellular vesicle (EV) isolation from human milk.

\begin{tabular}{|c|c|c|}
\hline Reference & EV Isolation & EV Experiment \\
\hline [11] & $\begin{array}{l}\text { 1. Differential centrifugation } \\
\text { 2. Filtration } \\
\text { 3. Differential and ultra-centrifugation } \\
\text { 4. Sucrose gradient }\end{array}$ & LC-MS/MS \\
\hline [72] & $\begin{array}{l}\text { 1. Differential centrifugation } \\
\text { 2. Filtration } \\
\text { 3. Ultracentrifugation } \\
\text { 4. Sucrose gradient } \\
\text { 5. Ultra-centrifugation }\end{array}$ & Characterization assays \\
\hline [91] & $\begin{array}{l}\text { 1. Differential centrifugation } \\
\text { 2. ExoQuick Exosome Isolation Kit }\end{array}$ & Cell culture treatments \\
\hline [73] & $\begin{array}{l}\text { 1. Differential centrifugation } \\
\text { 2. Sucrose gradient } \\
\text { 3. Ultra-centrifugation }\end{array}$ & Proteomic characterization of vesicles \\
\hline
\end{tabular}


Table 1. Cont.

\begin{tabular}{|c|c|c|}
\hline Reference & EV Isolation & EV Experiment \\
\hline [74] & $\begin{array}{l}\text { 1. Differential and ultra-centrifugation } \\
\text { 2. Filtration } \\
\text { 3. Sucrose gradient } \\
\text { 4. Filtration }\end{array}$ & iTRAQ-coupled LC-MS/MS \\
\hline [49] & $\begin{array}{l}\text { 1. Differential centrifugation } \\
\text { 2. Filtration } \\
\text { 3. ExoQuick-TC solution kit }\end{array}$ & Cell culture treatments \\
\hline [92] & $\begin{array}{l}\text { 1. Differential centrifugation } \\
\text { 2. Filtration } \\
\text { 3. ExoQuick Exosome Precipitation Solution } \\
\text { 4. Centrifugation }\end{array}$ & miR analysis \\
\hline$[28,56]$ & $\begin{array}{l}\text { 1. Differential centrifugation } \\
\text { 2. Filtration } \\
\text { 3. Ultra-centrifugation }\end{array}$ & $\begin{array}{l}\text { Cell culture treatments; iTRAQ-coupled } \\
\text { LC-(ESI)-MS/MS }\end{array}$ \\
\hline [55] & $\begin{array}{l}\text { 1. Differential centrifugation } \\
\text { 2. Filtration } \\
\text { 3. ExoQuick-TC solution kit }\end{array}$ & Next-generation sequencing, in vitro assays \\
\hline [31] & 1. Differential and ultra-centrifugation & Cell culture, in vivo treatments \\
\hline
\end{tabular}

\section{Preparation of Human Milk Extracellular Vesicles for Mass Spectrometry}

To date, few protocols are available for the preparation of HM EVs for liquid chromatography and mass spectrometry $[11,56,73,74]$. Bottom-up proteomics are commonly used for EV analyses, where all proteins are first digested and then peptides are separated prior to analysis in a mass spectrometer [93-95]. Specific to sample preparation, trypsin digestion optimization is needed to obtain maximal digestion of arginyl and lysyl peptide bonds in human milk exosome proteins.

EV sample preparation can include a variety of surfactants, e.g., SDS, n-dodecyl $\beta$ D-maltoside (DDM), and Triton X-100, which are used to prepare proteins with varying efficiency, depending on the sample type, for trypsin digestion [96-99]. Prior studies on human milk exosomes utilized different concentrations of sodium dodecyl sulfate in a denaturing buffer with Tris- $\mathrm{HCl}$ and urea, yielding reliable analysis [11,74]. Following digestion, de-salting of the sample avoids damage to the liquid chromatography and mass spectrometry equipment. There are multiple kits available for sample cleanup, e.g., ZipTips [100]. Either prior to or following digestion, peptides can be fractionated using chromatography techniques before running the milk-derived EV sample in a tandem mass spectrometer. This can be beneficial in order to separate peptides and can help better characterize the diverse exosomal protein content [88].

Multiple fractionation approaches have been used to separate exosomal peptides, which generally include a two-step separation. For human milk exosome samples, strong cation exchange chromatography (SCX) coupled with reverse phase was used by Admyre et al. (2007), as well as Yang et al. (2017) (Supplementary Table S1). In Van Herwijnen et al. (2016), in-gel digestion and separation were performed. In all cases, second phase separation utilized nano-liquid chromatography instrumentation. Proteomics studies on EVs from other biological sources have also included gel separation of intact proteins prior to digestion, followed by reverse phase separation [95], or two reverse phase separations with varied conditions [94]. The primary separation step might be omitted for proteomics characterization. For this one step approach it would be worthwhile to consider whether: (1) sufficiently pure EV sample is obtained; (2) optimal trypsin digestion conditions are developed; and (3) high performance or nano-liquid chromatography is used coupled with high-resolution tandem mass spectrometry for peptide separation and analysis. 


\section{Mass Spectrometry and Proteomics of Human Milk Extracellular Vesicles}

The use of the tandem mass spectrometer allows distinct selection of precursor and fragmentation ions for detection, obtaining high confidence protein matches [101]. Admyre et al. in 2007 used QSTAR Pulsar mass spectrometer, which couples to both matrixassisted laser desorption ionization (MALDI) and electrospray ionization (ESI), suitable for sequencing proteins in a wide mass range. Both Van Herwijen et al. (2016) and Yang et al. (2017) used a Q-Exactive instrument, where precursor ions were acquired using orbitrap, and ten most intense precursors were sent to fragmentation using high-energy C-trap dissociation (HCD). Use of HCD can increase the number of identified peptides, which is an advantage of the Q-Exactive instrument [102]. The most recent study by Wang et al. (2019) utilized Triple TOF 5600 Plus, which is a triple quadrupole coupled with time of flight mass analyzer and allows for a variety of mass scans [103].

Depending on the research question, mass spectrometry spectra can be generated and analyzed based on data-dependent acquisition (DDA) or data-independent acquisition (DIA) for global characterization of samples, or using multiple reaction monitoring (MRM) for specific EV components, e.g., for distinct cell membrane proteins [104]. In many current HM EV studies, DDA is used in tandem mass spectrometry, where selected high abundance precursor ions from MS1 are sent for fragmentation and detection in an MS2 scan [11,56,88]. The resulting spectra are queried in databases, using searching algorithms such as Sequest, Mascot, X!Tandem and/or Andromeda/MaxQuant, for matches and generation of the corresponding derived protein list [88]. In the 2007 study by Admyre et al., the authors identified over 70 proteins using a label-free technique; in comparison to Yang et al. (2017), where the authors reported over 900 proteins from bovine and human milk exosomes using iTRAQ labeling [36].

New strategies have been developed for DIA, e.g., sequential window acquisition of all theoretical fragment ion spectra (SWATH) and $\mathrm{MS}^{\mathrm{E}}[88,105-107]$. They allow selection of the majority of precursor ions in a selected window of the MS spectrum to be sent on to fragmentation simultaneously $[107,108]$. This method could identify low abundance proteins, which would otherwise remain undetected or characterized as noise in MS spectra [107]. In small EV characterization, it would be beneficial to identify proteins of lower abundance [105]. Two recent studies of urine extracellular vesicles and exosomes utilized $\mathrm{MS}^{\mathrm{E}}$ and SWATH, which allowed high confidence identification of 888 and 1877 proteins respectively at less than $1 \%$ false discovery rate for the former $[109,110]$. However, these DIA methodologies are still being developed and remain untested on milk EVs.

For quantitative and comparative proteomics, both label-free and isobaric labeling methods have been developed and reported. Label-free techniques can be beneficial and cost-effective for a more thorough characterization of EVs. However, they are more sensitive to differences in sample preparation and external factors when compared to isobaric labeling $[101,105]$. When sample comparisons are required, e.g., differences in term or preterm HM, a labeling technique is useful to compare and quantify the number and concentration of proteins in distinct sample populations [56]. To date, four studies have specifically characterized human milk EVs using data dependent acquisition method with or without label-free or isobaric labeling for quantitative analysis and sample comparisons (Supplementary Table S1) $[11,56,73,74]$. Isobaric labeling has been informative in studies of bovine- and human-milk derived EVs, which determined that EVs differ depending on biological source and disease state $[20,72,74]$. These findings have raised interest in milk biomarkers to advise on biological status and can rely on the aforementioned proteomics approaches for identification.

\section{Digestion Optimization for Label-Free Mass Spectrometry of Human Milk Extracellular Vesicles}

We performed protein solubilization optimization on term HM small EV samples to test seven detergents and determine the optimal milieu allowing maximal digestion of arginine- and lysine-involving peptide bonds in HM EV proteins. HM was collected 
from mothers following term birth, wherein colostrum was excluded. Between 15-20 mL of milk was collected per mother and processed immediately. Briefly, whole HM was centrifuged twice at $4600 \times g$ for $30 \mathrm{~min}$, at room temperature initially and $4{ }^{\circ} \mathrm{C}$ for the second centrifugation, to remove fat and cellular debris. The remaining skim layer was centrifuged at $20,000 \times g$ for $30 \mathrm{~min}$ at $4{ }^{\circ} \mathrm{C}$ to pellet vesicles larger than $200 \mathrm{~nm}$. The middle layer was then ultra-centrifuged twice at $100,000 \times g$ for $1.5 \mathrm{~h}$ at $4{ }^{\circ} \mathrm{C}$. The resultant EV pellet was resuspended in sterile $\mathrm{PBS}$ for storage in $-80^{\circ} \mathrm{C}$ until experiment.

SDS with and without EDTA at $5 \mathrm{mM}, 10 \mathrm{mM}$ and $34 \mathrm{mM}$ concentrations, Digitonin, n-dodecyl $\beta$-D-maltoside (DDM), and Triton X-100 were tested as detergents to allow for Trypsin/Lys-C to cleave peptides and be identified with liquid chromatography tandem mass spectrometry (LC-MS/MS). The detergents were added to samples in 1:4 ratio, respectively, and vortexed for five seconds. Following processing, $30 \mu \mathrm{g}$ of each sample was desalted using TopTips (Fisher Scientific, Waltham, MA, USA). The samples were then eluted three times with $50 \mu \mathrm{L}$ of $70 \%$ acetonitrile, $30 \%$ water and $0.1 \%$ formic acid and placed in a speed vacuum to dry. The samples were run on the Thermo Scientific ${ }^{\mathrm{TM}}$ Orbitrap Fusion $^{\mathrm{TM}}$ Tribrid $^{\mathrm{TM}}$ (Waltham, MA, USA).

The number of protein IDs identified with high and medium confidence using different detergents DDM, Digitonin, Triton X-100, SDS, SDS 5 mM EDTA, SDS $10 \mathrm{mM}$ EDTA and SDS 34 mM EDTA was 693, 667, 724, 728, 692, 721, 681, respectively (Figure 2). Digesting the EVs with SDS as the detergent provided the highest number of protein IDs (728), as well as 57 unique proteins (Figure 3). However, the most unique proteins (100) were detected using SDS with $34 \mathrm{mM}$ EDTA (Figure 3).

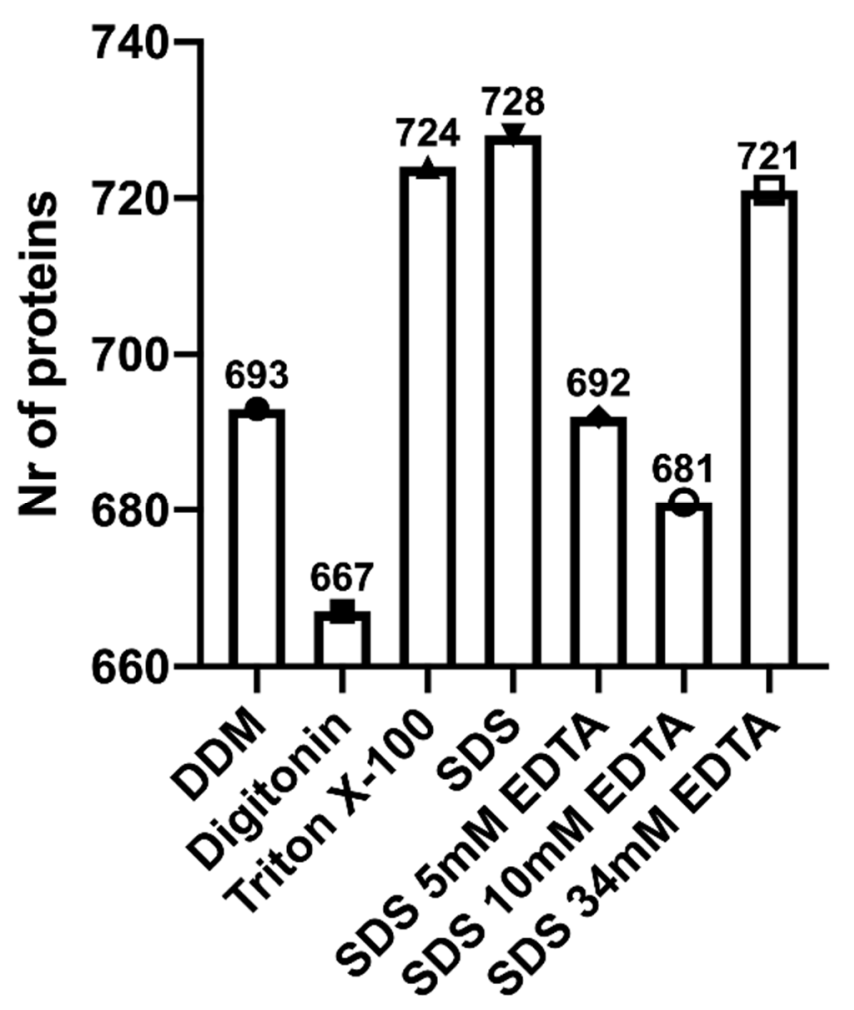

Figure 2. Number of high and medium confidence proteins identified following tandem-MS/MS analysis of human milk extracellular vesicles under seven different denaturing conditions. SDS with and without EDTA at $5 \mathrm{mM}, 10 \mathrm{mM}$ and $34 \mathrm{mM}$ concentrations, Digitonin, $\mathrm{n}$-dodecyl $\beta$-D-maltoside (DDM), and Triton $\mathrm{X}-100$ were tested as detergents, $\mathrm{n}=1$. Mass spectrometry analysis from samples processed with each detergent revealed Triton X-100, SDS and SDS with $34 \mathrm{mM}$ of EDTA to be the optimal detergent based on the highest number of proteins identified. 


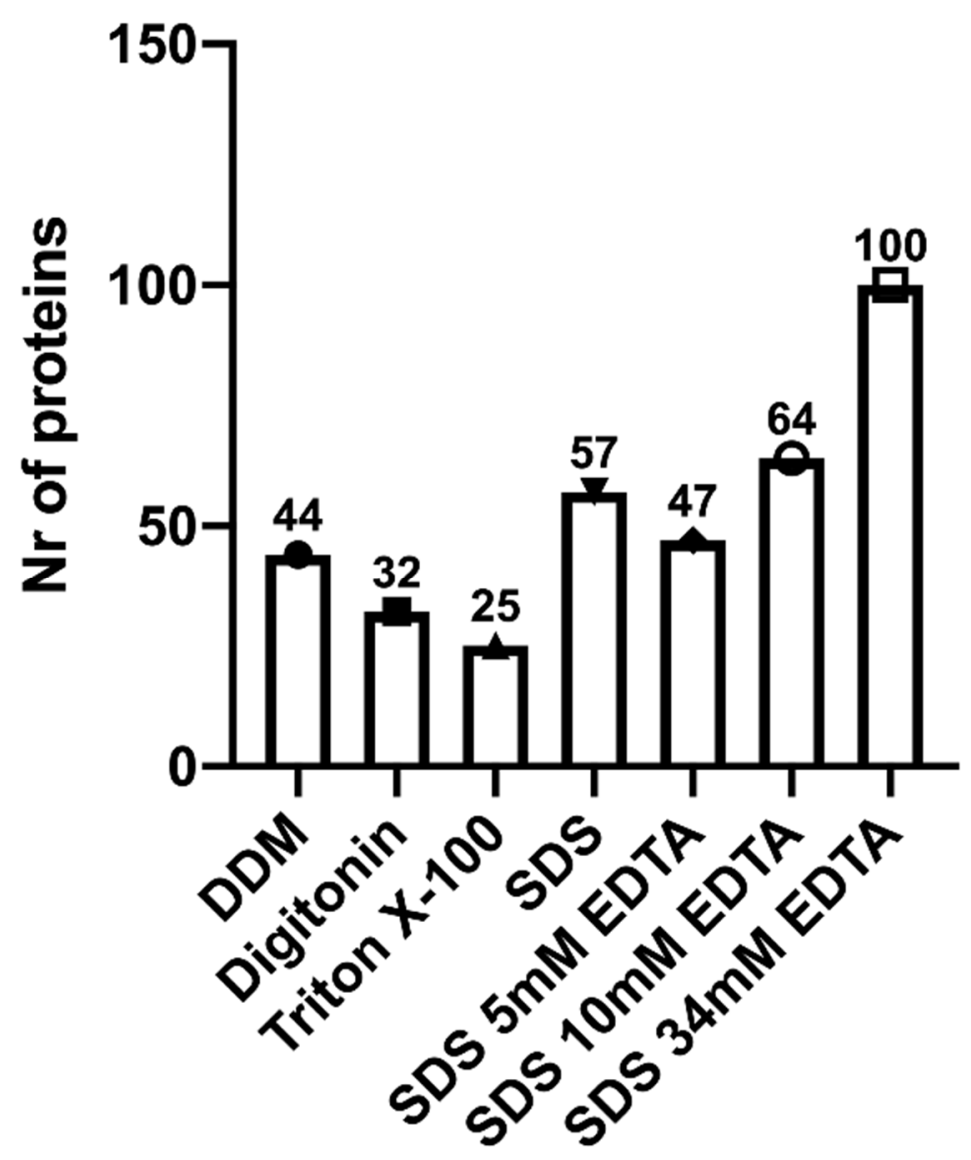

Figure 3. Number of high confidence unique proteins identified following tandem-MS/MS analysis of human milk extracellular vesicles under seven different denaturing conditions. SDS with and without EDTA at $5 \mathrm{mM}, 10 \mathrm{mM}$ and $34 \mathrm{mM}$ concentrations, Digitonin, $\mathrm{n}$-dodecyl $\beta$-D-maltoside (DDM), and Triton $\mathrm{X}-100$ were tested as detergents, $\mathrm{n}=1$. Mass spectrometry analysis from samples processed with each detergent revealed SDS with $34 \mathrm{mM}$ of EDTA to be the optimal detergent based on the highest number of unique proteins identified.

\section{Bioinformatics Approaches to Human Milk Extracellular Vesicles}

Following protein detection, we selected high confidence proteins from all treatments to identify corresponding biological processes using GOrilla [111]. The redundant GO terms were then removed in REVIGO [112] and an updated list of biological processes was obtained. DDM, Digitonin and SDS treatment groups identified the most biological processes (Figure 4). SDS EDTA $34 \mathrm{mM}$ treatment resulted in a narrow biological process identification, though this treatment resulted in identification of most unique proteins (Figure 3). Body fluid secretion and lactation were identified across all treatments (Figure 4), indicating that these processes may be conserved across HM small EVs and serve as a benchmark for sample processing in proteomics. 


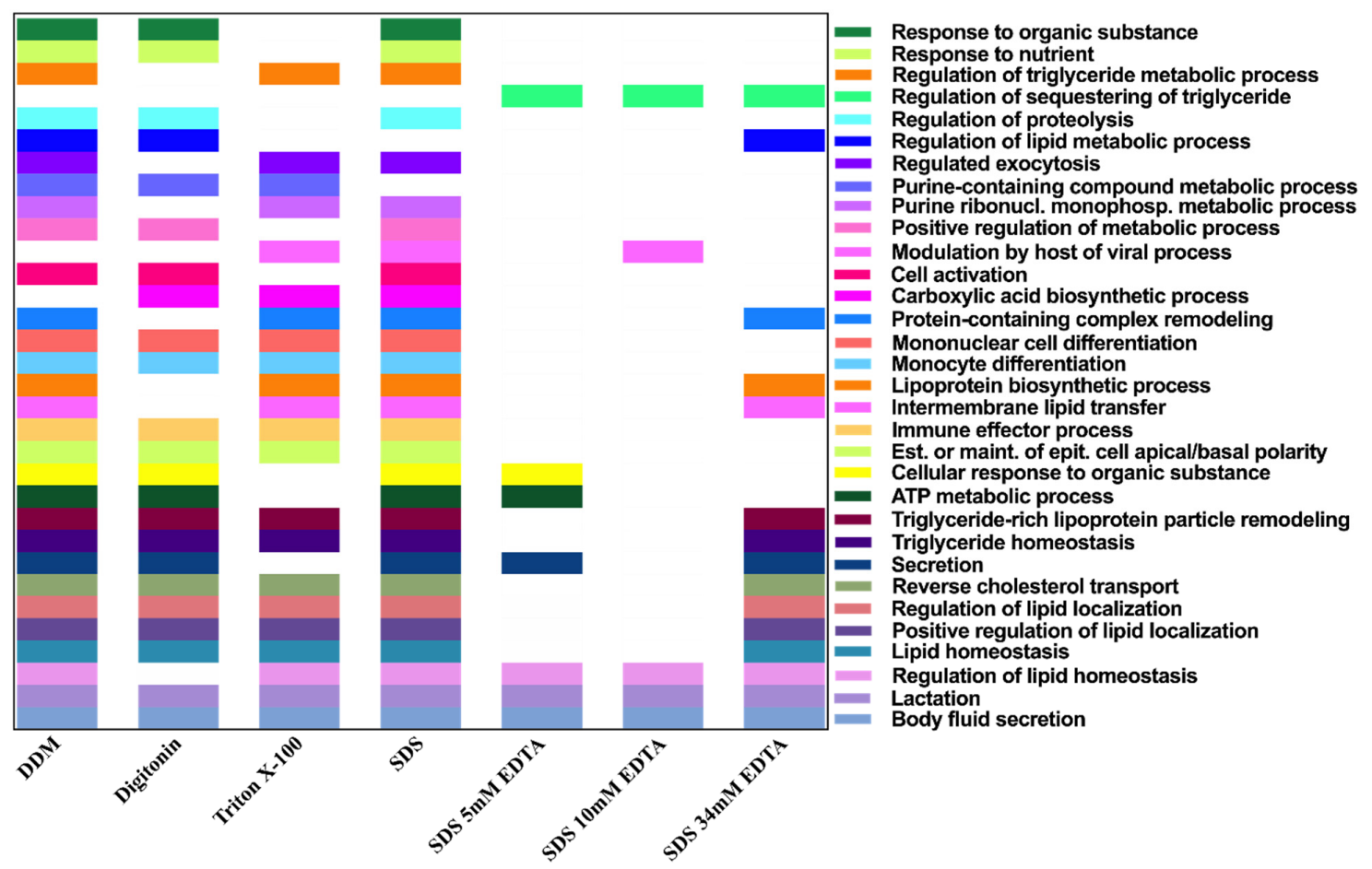

Figure 4. Biological processes corresponding to high confidence proteins detected in human milk extracellular vesicles processed under seven different denaturing conditions. Biological processes that were common to three or more conditions are shown. Highest number of biological processes were identified from human milk extracellular vesicle samples processed with SDS and DDM. Lactation and body fluid secretion were identified across samples under different denaturing conditions. REVIGO analysis of significant GO terms identified by GOrilla analysis, following removal of redundant terms.

The number of proteins identified is important for downstream analyses, as well as detection of specific proteins in individual samples. Downstream bioinformatics analyses can provide answers to narrower research questions. To aid such approaches, multiple research groups have submitted their exosome and/or vesicle proteomics results to custom-curated databases, which include ExoCarta [113], Vesiclepedia [114], and EVpedia [115]. EVpedia and ExoCarta were the first available databases for EVs and exosomes [116,117]. EVpedia contains proteins from hundreds of proteome sets obtained from EVs [88]. ExoCarta has a substantial amount of entries from exosomal components, including proteins, lipids, mRNA and miRs, and 81 entries corresponding to human milk [34]. Similar to EVpedia, Vesiclepedia has a wide variety of entries from EVs, including proteins and lipids [34,118]. Therefore, protein matches obtained from database search algorithms (e.g., Mascot) can also be queried in exosomal databases to compare sample variability, disease states and more.

Further enrichment analyses of data can be helpful to identify interacting proteins or networks. Several of such databases are available, including STRING, Profiler, GSEA, Cytoscape and EnrichmentMap [119,120]. Additionally, FunRich, a functional enrichment tool, allows integration with Vesiclepedia, making it a useful tool for EV-omics [121].

\section{Conclusions}

Preparing human milk small EVs for bottom-up proteomics is a multi-factorial process (Figure 5, Supplementary Table S2). The first step is sample isolation where the most frequently used technique is differential and ultra-centrifugation, with or without a sucrose gradient. Once small EVs are isolated and confirmed, samples can be prepared for mass spectrometry analysis. Proteins should then be digested and solubilized with a detergent of choice, depending on analysis end-goal and to minimize damage to mass spectrometry equipment. In our experiment, highest number of proteins were detected using SDS with 34 mM EDTA (Figure 2). Peptides should then be separated either in a one or two-step chro- 
matography process, preferably using reverse phase nano-liquid chromatography, followed by analysis in a tandem mass spectrometer, where various high-resolution analyzers have been used in previous studies (Supplementary Table S1). If the research question requires sample comparisons or quantification, label-free or isobaric labeling techniques should be used. The latter needs to be added to the sample prior to or following trypsinization. If global protein analysis is the goal, no labeling is required, and data dependent acquisition can be used. Newer approaches in data independent acquisition (e.g., SWATH, MS ${ }^{\mathrm{E}}$ ) can also be utilized $[106,109]$, however, pilot experiments should be conducted for validation of analyses in milk EVs and exosomes.

Human milk small EVs can contribute to our understanding of systemic signaling, nutritional enrichment, immune regulation and much more. EV research relies on accurate proteomics findings to inform on proteins of interest, characterize modes of interactions, and downstream effects of human milk EVs and exosomes. It is essential to obtain reproducible data from human milk small EVs. This bio-analytical field continues to grow, co-evolving with developments in proteomics approaches. The strategies outlined in this review are currently in-use for the intricate process of small EV isolation and analysis, however, new emerging methods will no doubt inform and improve on the processes. For example, the use of data independent acquisition approach may yield even more detailed information about EV-associated proteins.

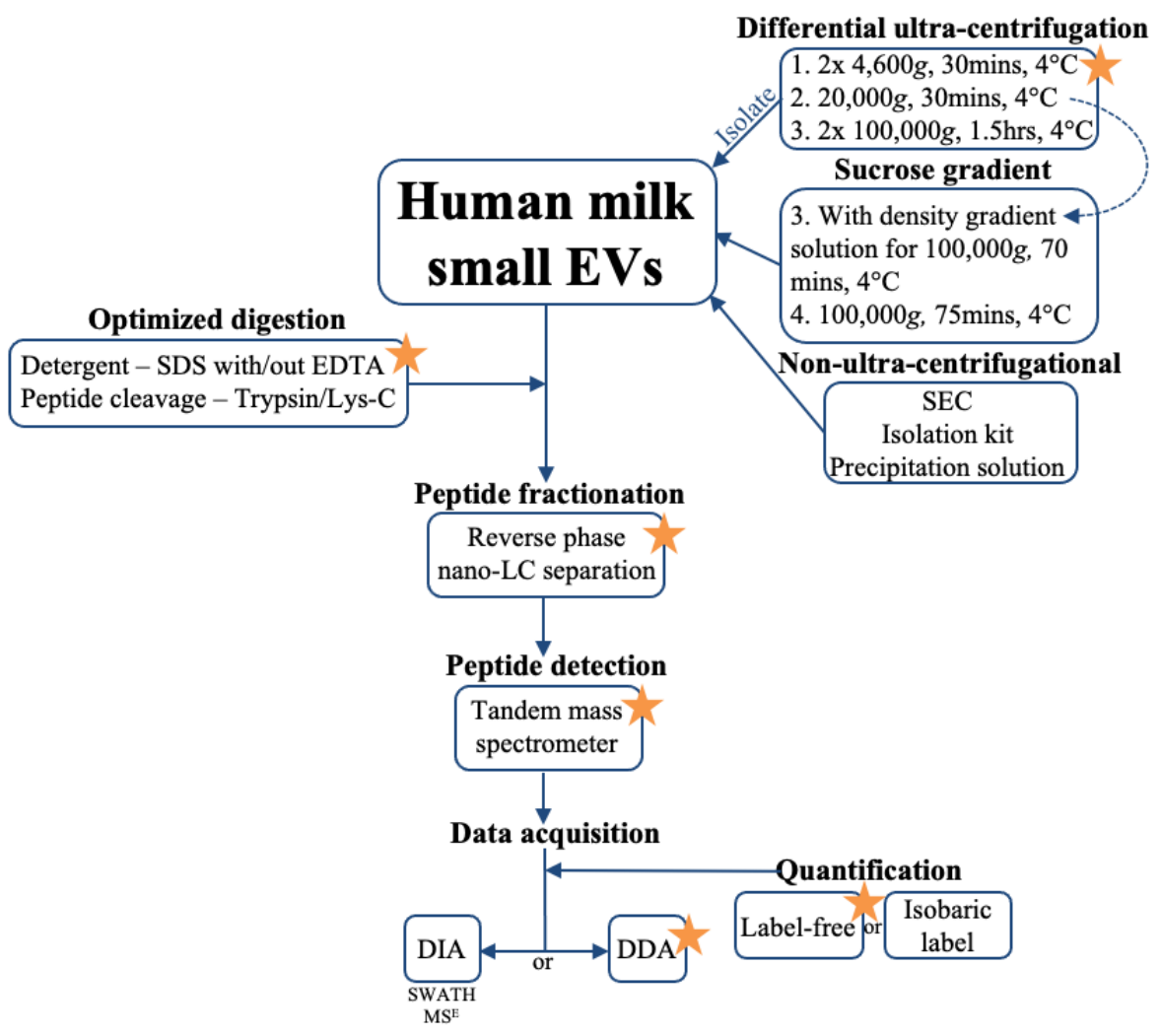

Figure 5. Workflow for human milk small extracellular vesicle (EV) bottom-up proteomics. Human milk small EVs can be isolated using differential centrifugation with or without sucrose gradient, or using non-ultra-centrifugational methods (SEC-size exclusion chromatography). Protein digestion can be achieved using an SDS detergent with or without EDTA, following peptide cleavage with Trypsin/Lys/C, however solubilization agents and trypsinization should be optimized for each experiment depending on analysis end-goals. Chromatographic fractionation of peptides follows, which can include reverse phase nano-liquid chromatography (nano-LC). Peptides are detected by tandem mass spectrometer and data acquired using data independent acquisition (DIA: SWATH-Sequential Windowed Acquisition of All Theoretical Fragment Ion; $\mathrm{MS}^{\mathrm{E}}$ ), or data dependent acquisition (DDA), which can be coupled with label-free or isobaric labeling of EV sample. Orange star emphasizes suggested method for use in human milk EV proteomics, as identified in prior publications on human milk EV proteomic analyses. 
Supplementary Materials: The following are available online at https: / www.mdpi.com/article/ 10.3390/biom11060833/s1, Table S1: Summary of published sample preparations for proteomics analyses of human milk extracellular vesicles, Table S2: Summary of advantages and disadvantages of methods recommended for human milk extracellular proteomics.

Funding: This work was supported by the Ministry of Economic Development, Job Creation and Trade Ontario under grant LCIF-BC140, and Canadian Institutes of Health Research under grant PJT-162423.

Acknowledgments: The authors would like to extend their sincerest thank you to Maxim Berezovski and Zoran Minic for assistance with mass spectrometry, to Eric Tremblay, Nicholas LeBlond, Kiah Barton and Evelin Loit for invaluable advice and assistance.

Conflicts of Interest: The authors declare no conflict of interest.

\section{References}

1. Petherick, A. Development: Mother's Milk: A Rich Opportunity. Nature 2010, 468, S5-S7. [CrossRef]

2. Ballard, O.; Morrow, A.L. Human Milk Composition. Pediatr. Clin. N. Am. 2013, 60, 49-74. [CrossRef] [PubMed]

3. Ojo-Okunola, A.; Cacciatore, S.; Nicol, M.P.; du Toit, E. The Determinants of the Human Milk Metabolome and Its Role in Infant Health. Metabolites 2020, 10, 77. [CrossRef]

4. Schanler, R.J.; Shulman, R.J.; Lau, C. Feeding Strategies for Premature Infants: Beneficial Outcomes of Feeding Fortified Human Milk versus Preterm Formula. Pediatrics 1999, 103, 1150-1157. [CrossRef]

5. Newburg, D.S. Bioactive Components of Human Milk; Springer: Boston, MA, USA, 2001; pp. 3-10. [CrossRef]

6. Underwood, M.A. Human Milk for the Premature Infant. Pediatr. Clin. N. Am. 2013, 60, 189-207. [CrossRef]

7. Bauer, J.; Gerss, J. Longitudinal Analysis of Macronutrients and Minerals in Human Milk Produced by Mothers of Preterm Infants. Clin. Nutr. 2011, 30, 215-220. [CrossRef] [PubMed]

8. Rani, P.; Yenuganti, V.R.; Shandilya, S.; Onteru, S.K.; Singh, D. MiRNAs: The Hidden Bioactive Component of Milk. Trends Food Sci. Technol. 2017, 65, 94-102. [CrossRef]

9. Kosaka, N.; Izumi, H.; Sekine, K.; Ochiya, T. MicroRNA as a New Immune-Regulatory Agent in Breast Milk. Silence 2010, 1, 7. [CrossRef]

10. Ward, T.L.; Hosid, S.; Ioshikhes, I.; Altosaar, I. Human Milk Metagenome: A Functional Capacity Analysis. BMC Microbiol. 2013, 13, 116. [CrossRef]

11. Admyre, C.; Johansson, S.M.; Qazi, K.R.; Filén, J.-J.; Lahesmaa, R.; Norman, M.; Neve, E.P.A.; Scheynius, A.; Gabrielsson, S. Exosomes with Immune Modulatory Features Are Present in Human Breast Milk. J. Immunol. 2007, 179, 1969-1978. [CrossRef] [PubMed]

12. Gianni, M.L.; Bezze, E.N.; Sannino, P.; Baro, M.; Roggero, P.; Muscolo, S.; Plevani, L.; Mosca, F. Maternal Views on Facilitators of and Barriers to Breastfeeding Preterm Infants. BMC Pediatr. 2018, 18, 283. [CrossRef]

13. Herrmann, K.; Carroll, K. An Exclusively Human Milk Diet Reduces Necrotizing Enterocolitis. Breastfeed. Med. 2014, 9, 184-190. [CrossRef]

14. Cheng, Y.-J.; Yeung, C.-Y. Recent Advance in Infant Nutrition: Human Milk Oligosaccharides. Pediatr. Neonatol. 2021. [CrossRef] [PubMed]

15. Chouraqui, J.-P. Does the Contribution of Human Milk Oligosaccharides to the Beneficial Effects of Breast Milk Allow Us to Hope for an Improvement in Infant Formulas? Crit. Rev. Food Sci. Nutr. 2021, 61, 1503-1514. [CrossRef] [PubMed]

16. Hewelt-Belka, W.; Garwolińska, D.; Młynarczyk, M.; Kot-Wasik, A. Comparative Lipidomic Study of Human Milk from Different Lactation Stages and Milk Formulas. Nutrients 2020, 12, 2065. [CrossRef] [PubMed]

17. Yu, H.; Dilbaz, S.; Coßmann, J.; Hoang, A.C.; Diedrich, V.; Herwig, A.; Harauma, A.; Hoshi, Y.; Moriguchi, T.; Landgraf, K. Breast Milk Alkylglycerols Sustain Beige Adipocytes through Adipose Tissue Macrophages. J. Clin. Investig. 2019, 129, $2485-2499$. [CrossRef]

18. Floris, I.; Billard, H.; Boquien, C.Y.; Joram-Gauvard, E.; Simon, L.; Legrand, A.; Boscher, C.; Rozé, J.C.; Bolaños-Jiménez, F.; Kaeffer, B. MiRNA Analysis by Quantitative PCR in Preterm Human Breast Milk Reveals Daily Fluctuations of Hsa-MiR-16-5p. PLoS ONE 2015, 10, e0140488. [CrossRef]

19. Floris, I.; Kraft, J.; Altosaar, I. Roles of MicroRNA across Prenatal and Postnatal Periods. Int. J. Mol. Sci. 2016, 17, 1994. [CrossRef]

20. Sun, J.; Aswath, K.; Schroeder, S.G.; Lippolis, J.D.; Reinhardt, T.A.; Sonstegard, T.S. MicroRNA Expression Profiles of Bovine Milk Exosomes in Response to Staphylococcus Aureus Infection. BMC Genom. 2015, 16. [CrossRef]

21. Sun, Q.; Chen, X.; Yu, J.; Zen, K.; Zhang, C.-Y.; Li, L. Immune Modulatory Function of Abundant Immune-Related MicroRNAs in Microvesicles from Bovine Colostrum. Protein Cell 2013, 4, 197-210. [CrossRef]

22. Leiferman, A.; Shu, J.; Upadhyaya, B.; Cui, J.; Zempleni, J. Storage of Extracellular Vesicles in Human Milk, and MicroRNA Profiles in Human Milk Exosomes and Infant Formulas. J. Pediatr. Gastroenterol. Nutr. 2019, 69, 235-238. [CrossRef]

23. Golan-Gerstl, R.; Elbaum Shiff, Y.; Moshayoff, V.; Schecter, D.; Leshkowitz, D.; Reif, S. Characterization and Biological Function of Milk-Derived MiRNAs. Mol. Nutr. Food Res. 2017, 61, 1700009. [CrossRef] [PubMed] 
24. Zhou, Q.; Li, M.; Wang, X.; Li, Q.; Wang, T.; Zhu, Q.; Zhou, X.; Wang, X.; Gao, X.; Li, X. Immune-Related MicroRNAs Are Abundant in Breast Milk Exosomes. Int. J. Biol. Sci. 2012, 8, 118-123. [CrossRef]

25. Shiff, Y.E.; Reif, S.; Marom, R.; Shiff, K.; Reifen, R.; Golan-Gerstl, R. MiRNA-320a Is Less Expressed and MiRNA-148a More Expressed in Preterm Human Milk Compared to Term Human Milk. J. Funct. Foods 2019, 57, 68-74. [CrossRef]

26. Mukhopadhya, A.; Santoro, J.; Moran, B.; Useckaite, Z.; O’Driscoll, L. Optimisation and Comparison of Orthogonal Methods for Separation and Characterisation of Extracellular Vesicles to Investigate How Representative Infant Milk Formula Is of Milk. Food Chem. 2021, 353, 129309. [CrossRef]

27. Bickmore, D.C.; Miklavcic, J.J. Characterization of Extracellular Vesicles Isolated from Human Milk Using a Precipitation-Based Method. Front. Nutr. 2020, 7, 22. [CrossRef]

28. Martin, C.; Patel, M.; Williams, S.; Arora, H.; Sims, B. Human Breast Milk-Derived Exosomes Attenuate Cell Death in Intestinal Epithelial Cells. Innate Immun. 2018, 24, 278-284. [CrossRef]

29. Miyake, H.; Lee, C.; Chusilp, S.; Bhalla, M.; Li, B.; Pitino, M.; Seo, S.; O'Connor, D.L.; Pierro, A. Human Breast Milk Exosomes Attenuate Intestinal Damage. Pediatr. Surg. Int. 2020, 36, 155-163. [CrossRef] [PubMed]

30. Chen, W.; Chen, X.; Qian, Y.; Wang, X.; Zhou, Y.; Yan, X.; Yu, B.; Yao, S.; Yu, Z.; Zhu, J.; et al. Lipidomic Profiling of Human Milk Derived Exosomes and Their Emerging Roles in the Prevention of Necrotizing Enterocolitis. Mol. Nutr. Food Res. 2021. [CrossRef] [PubMed]

31. Pisano, C.; Galley, J.; Elbahrawy, M.; Wang, Y.; Farrell, A.; Brigstock, D.; Besner, G.E. Human Breast Milk-Derived Extracellular Vesicles in the Protection against Experimental Necrotizing Enterocolitis. J. Pediatr. Surg. 2020, 55, 54-58. [CrossRef]

32. Galley, J.D.; Besner, G.E. The Therapeutic Potential of Breast Milk-Derived Extracellular Vesicles. Nutrients 2020, $12,745$. [CrossRef] [PubMed]

33. Kraft, J.D. Exosome Protein Diversity Is Greater in Preterm Milk than Term Milk. Ph.D. Thesis, University of Ottawa, Ottawa, ON, Canada, 2019.

34. Zempleni, J.; Aguilar-Lozano, A.; Sadri, M.; Sukreet, S.; Manca, S.; Wu, D.; Zhou, F.; Mutai, E. Biological Activities of Extracellular Vesicles and Their Cargos from Bovine and Human Milk in Humans and Implications for Infants. J. Nutr. 2017, 147, 3-10. [CrossRef]

35. Colombo, M.; Raposo, G.; Théry, C. Biogenesis, Secretion, and Intercellular Interactions of Exosomes and Other Extracellular Vesicles. Annu. Rev. Cell Dev. Biol. 2014, 30, 255-289. [CrossRef]

36. De la Torre Gomez, C.; Goreham, R.V.; Bech Serra, J.J.; Nann, T.; Kussmann, M. “Exosomics”—A Review of Biophysics, Biology and Biochemistry of Exosomes with a Focus on Human Breast Milk. Front. Genet. 2018, 9, 92. [CrossRef] [PubMed]

37. Lotvall, J.; Valadi, H. Cell to Cell Signalling via Exosomes through EsRNA. Cell Adhes. Migr. 2007, 156-158. [CrossRef] [PubMed]

38. Valadi, H.; Ekström, K.; Bossios, A.; Sjöstrand, M.; Lee, J.J.; Lötvall, J.O. Exosome-Mediated Transfer of MRNAs and MicroRNAs Is a Novel Mechanism of Genetic Exchange between Cells. Nat. Cell Biol. 2007, 9, 654-659. [CrossRef] [PubMed]

39. Jeppesen, D.K.; Fenix, A.M.; Franklin, J.L.; Higginbotham, J.N.; Zhang, Q.; Zimmerman, L.J.; Liebler, D.C.; Ping, J.; Liu, Q.; Evans, R.; et al. Reassessment of Exosome Composition. Cell 2019, 177, 428-445. [CrossRef] [PubMed]

40. Pluchino, S.; Smith, J.A. Explicating Exosomes: Reclassifying the Rising Stars of Intercellular Communication. Cell 2019, 225-227. [CrossRef]

41. Harding, C.; Heuser, J.; Stahl, P. Receptor-Mediated Endocytosis of Transferrin and Recycling of the Transferrin Receptor in Rat Reticulocytes. J. Cell Biol. 1983, 97, 329-339. [CrossRef]

42. Pan, B.T.; Johnstone, R.M. Fate of the Transferrin Receptor during Maturation of Sheep Reticulocytes In Vitro: Selective Externalization of the Receptor. Cell 1983, 33, 967-978. [CrossRef]

43. Kowal, J.; Arras, G.; Colombo, M.; Jouve, M.; Morath, J.P.; Primdal-Bengtson, B.; Dingli, F.; Loew, D.; Tkach, M.; Théry, C. Proteomic Comparison Defines Novel Markers to Characterize Heterogeneous Populations of Extracellular Vesicle Subtypes. Proc. Natl. Acad. Sci. USA 2016, 113, E968-E977. [CrossRef]

44. Lawson, C.; Vicencio, J.M.; Yellon, D.M.; Davidson, S.M. Microvesicles and Exosomes: New Players in Metabolic and Cardiovascular Disease. J. Endocrinol. 2016, 228, R57-R71. [CrossRef] [PubMed]

45. Théry, C.; Witwer, K.W.; Aikawa, E.; Alcaraz, M.J.; Anderson, J.D.; Andriantsitohaina, R.; Antoniou, A.; Arab, T.; Archer, F.; Atkin-Smith, G.K.; et al. Minimal Information for Studies of Extracellular Vesicles 2018 (MISEV2018): A Position Statement of the International Society for Extracellular Vesicles and Update of the MISEV2014 Guidelines. J. Extracell. Vesicles 2018, 7, 1535750. [CrossRef] [PubMed]

46. Manca, S.; Upadhyaya, B.; Mutai, E.; Desaulniers, A.T.; Cederberg, R.A.; White, B.R.; Zempleni, J. Milk Exosomes Are Bioavailable and Distinct MicroRNA Cargos Have Unique Tissue Distribution Patterns. Sci. Rep. 2018, 8. [CrossRef]

47. Agrawal, A.K.; Aqil, F.; Jeyabalan, J.; Spencer, W.A.; Beck, J.; Gachuki, B.W.; Alhakeem, S.S.; Oben, K.; Munagala, R.; Bondada, S.; et al. Milk-Derived Exosomes for Oral Delivery of Paclitaxel. Nanomedicine 2017, 13, 1627-1636. [CrossRef] [PubMed]

48. Pieters, B.C.H.; Arntz, O.J.; Bennink, M.B.; Broeren, M.G.A.; van Caam, A.P.M.; Koenders, M.I.; van Lent, P.L.E.M.; van den Berg, W.B.; de Vries, M.; van der Kraan, P.M.; et al. Commercial Cow Nilk Contains Physically Stable Extracellular Vesicles Expressing Immunoregulatory TGF- $\beta$. PLoS ONE 2015, 10, e0121123. [CrossRef] [PubMed]

49. Liao, Y.; Du, X.; Li, J.; Lönnerdal, B. Human Milk Exosomes and Their MicroRNAs Survive Digestion In Vitro and Are Taken up by Human Intestinal Cells. Mol. Nutr. Food Res. 2017, 61, 1700082. [CrossRef] [PubMed] 
50. Izumi, H.; Tsuda, M.; Sato, Y.; Kosaka, N.; Ochiya, T.; Iwamoto, H.; Namba, K.; Takeda, Y. Bovine Milk Exosomes Contain MicroRNA and MRNA and Are Taken up by Human Macrophages. J. Dairy Sci. 2015, 98, 2920-2933. [CrossRef]

51. Lässer, C.; Seyed Alikhani, V.; Ekström, K.; Eldh, M.; Torregrosa Paredes, P.; Bossios, A.; Sjöstrand, M.; Gabrielsson, S.; Lötvall, J.; Valadi, H. Human Saliva, Plasma and Breast Milk Exosomes Contain RNA: Uptake by Macrophages. J. Transl. Med. 2011, 9, 9. [CrossRef]

52. Baier, S.R.; Nguyen, C.; Xie, F.; Wood, J.R.; Zempleni, J. MicroRNAs Are Absorbed in Biologically Meaningful Amounts from Nutritionally Relevant Doses of Cow Milk and Affect Gene Expression in Peripheral Blood Mononuclear Cells, HEK-293 Kidney Cell Cultures, and Mouse Livers. J. Nutr. 2014, 144, 1495-1500. [CrossRef]

53. Kusuma, R.J.; Manca, S.; Frieme, T.; Sukreet, S.; Nguyen, C.; Zempleni, J. Human Vascular Endothelial Cells Transport Foreign Exosomes from Cow's Milk by Endocytosis. Am. J. Physiol. Cell Physiol. 2016, 310, C800-C807. [CrossRef] [PubMed]

54. Rani, P.; Vashisht, M.; Golla, N.; Shandilya, S.; Onteru, S.K.; Singh, D. Milk MiRNAs Encapsulated in Exosomes Are Stable to Human Digestion and Permeable to Intestinal Barrier In Vitro. J. Funct. Foods 2017, 34, 431-439. [CrossRef]

55. Kahn, S.; Liao, Y.; Du, X.; Xu, W.; Li, J.; Lönnerdal, B. Exosomal Micrornas in Milk from Mothers Delivering Preterm Infants Survive In Vitro Digestion and Are Taken up by Human Intestinal Cells. Mol. Nutr. Food Res. 2018, 62, 1701050. [CrossRef] [PubMed]

56. Wang, X.; Yan, X.; Zhang, L.; Cai, J.; Zhou, Y.; Liu, H.; Hu, Y.; Chen, W.; Xu, S.; Liu, P.; et al. Identification and Peptidomic Profiling of Exosomes in Preterm Human Milk: Insights into Necrotizing Enterocolitis Prevention. Mol. Nutr. Food Res. 2019, 1801247. [CrossRef]

57. Hock, A.; Miyake, H.; Li, B.; Lee, C.; Ermini, L.; Koike, Y.; Chen, Y.; Määttänen, P.; Zani, A.; Pierro, A. Breast Milk-Derived Exosomes Promote Intestinal Epithelial Cell Growth. J. Pediatr. Surg. 2017, 52, 755-759. [CrossRef]

58. Reif, S.; Elbaum Shiff, Y.; Golan-Gerstl, R. Milk-Derived Exosomes (MDEs) Have a Different Biological Effect on Normal Fetal Colon Epithelial Cells Compared to Colon Tumor Cells in a MiRNA-Dependent Manner. J. Transl. Med. 2019, 17. [CrossRef] [PubMed]

59. Zonneveld, M.I.; van Herwijnen, M.J.C.; Fernandez-Gutierrez, M.M.; Giovanazzi, A.; de Groot, A.M.; Kleinjan, M.; van Capel, T.M.M.; Sijts, A.J.A.M.; Taams, L.S.; Garssen, J.; et al. Human Milk Extracellular Vesicles Target Nodes in Interconnected Signalling Pathways That Enhance Oral Epithelial Barrier Function and Dampen Immune Responses. J. Extracell. Vesicles 2021, 10, e12071. [CrossRef]

60. Slavov, N. Single-Cell Protein Analysis by Mass Spectrometry. Curr. Opin. Chem. Biol. 2021, 60, 1-9. [CrossRef]

61. Taylor, M.J.; Lukowski, J.K.; Anderton, C.R. Spatially Resolved Mass Spectrometry at the Single Cell: Recent Innovations in Proteomics and Metabolomics. J. Am. Soc. Mass Spectrom. 2021, 32, 872-894. [CrossRef]

62. Pino, L.K.; Rose, J.; O’Broin, A.; Shah, S.; Schilling, B. Emerging Mass Spectrometry-Based Proteomics Methodologies for Novel Biomedical Applications. Biochem. Soc. Trans. 2020, 48, 1953-1966. [CrossRef] [PubMed]

63. Yates, J.R. Innovations in Proteomics: The Drive to Single Cells. J. Proteome Res. 2018, 17, 2563-2564. [CrossRef] [PubMed]

64. Alexovič, M.; Urban, P.L.; Tabani, H.; Sabo, J. Recent Advances in Robotic Protein Sample Preparation for Clinical Analysis and Other Biomedical Applications. Clin. Chim. Acta 2020, 507, 104-116. [CrossRef]

65. Dupree, E.J.; Jayathirtha, M.; Yorkey, H.; Mihasan, M.; Petre, B.A.; Darie, C.C. A Critical Review of Bottom-up Proteomics: The Good, the Bad, and the Future of This Field. Proteomes 2020, 8, 14. [CrossRef] [PubMed]

66. Chapman, J.D.; Goodlett, D.R.; Masselon, C.D. Multiplexed and Data-Independent Tandem Mass Spectrometry for Global Proteome Profiling. Mass Spectrom. Rev. 2014, 33, 452-470. [CrossRef] [PubMed]

67. Phillips, W.; Willms, E.; Hill, A.F. Understanding Extracellular Vesicle and Nanoparticle Heterogeneity: Novel Methods and Considerations. Proteomics 2021, e2000118. [CrossRef]

68. Monaco, M.H.; Kim, J.; Donovan, S.M. Human Milk: Composition and Nutritional Value; Caballero, B., Finglas, P.M., Toldrá, F., Eds.; Academic Press: Oxford, UK, 2016; pp. 357-362. [CrossRef]

69. Théry, C.; Amigorena, S.; Raposo, G.; Clayton, A. Isolation and Characterization of Exosomes from Cell Culture Supernatants and Biological Fluids. Curr. Protoc. Cell Biol. 2006, 30. [CrossRef] [PubMed]

70. Zonneveld, M.I.; Brisson, A.R.; van Herwijnen, M.J.C.; Tan, S.; van de Lest, C.H.A.; Redegeld, F.A.; Garssen, J.; Wauben, M.H.M.; Hoen, E.N. Recovery of Extracellular Vesicles from Human Breast Milk Is Influenced by Sample Collection and Vesicle Isolation Procedures. J. Extracell. Vesicles 2014, 3, 24215. [CrossRef]

71. Crescitelli, R.; Lässer, C.; Jang, S.C.; Cvjetkovic, A.; Malmhäll, C.; Karimi, N.; Höög, J.L.; Johansson, I.; Fuchs, J.; Thorsell, A.; et al Subpopulations of Extracellular Vesicles from Human Metastatic Melanoma Tissue Identified by Quantitative Proteomics after Optimized Isolation. J. Extracell. Vesicles 2020, 9, 1722433. [CrossRef]

72. Torregrosa Paredes, P.; Gutzeit, C.; Johansson, S.; Admyre, C.; Stenius, F.; Alm, J.; Scheynius, A.; Gabrielsson, S. Differences in Exosome Populations in Human Breast Milk in Relation to Allergic Sensitization and Lifestyle. Allergy Eur. J. Allergy Clin. Immunol. 2014, 69, 463-471. [CrossRef]

73. Van Herwijnen, M.J.C.; Zonneveld, M.I.; Goerdayal, S.; Hoen, E.N.M.N.; Garssen, J.; Stahl, B.; Maarten Altelaar, A.F.; Redegeld, F.A.; Wauben, M.H.M. Comprehensive Proteomic Analysis of Human Milk-Derived Extracellular Vesicles Unveils a Novel Functional Proteome Distinct from Other Milk Components. Mol. Cell. Proteom. 2016, 15, 3412-3423. [CrossRef] 
74. Yang, M.; Song, D.; Cao, X.; Wu, R.; Liu, B.; Ye, W.; Wu, J.; Yue, X. Comparative Proteomic Analysis of Milk-Derived Exosomes in Human and Bovine Colostrum and Mature Milk Samples by ITRAQ-Coupled LC-MS/MS. Food Res. Int. 2017, $92,17-25$. [CrossRef] [PubMed]

75. Patel, G.K.; Khan, M.A.; Zubair, H.; Srivastava, S.K.; Khushman, M.; Singh, S.; Singh, A.P. Comparative Analysis of Exosome Isolation Methods Using Culture Supernatant for Optimum Yield, Purity and Downstream Applications. Sci. Rep. 2019, 9. [CrossRef]

76. Gámez-Valero, A.; Monguió-Tortajada, M.; Carreras-Planella, L.; Franquesa, M.; Beyer, K.; Borràs, F.E. Size-Exclusion Chromatography-Based Isolation Minimally Alters Extracellular Vesicles' Characteristics Compared to Precipitating Agents. Sci. Rep. 2016, 6, 33641. [CrossRef] [PubMed]

77. Navajas, R.; Corrales, F.J.; Paradela, A. Serum Exosome Isolation by Size-Exclusion Chromatography for the Discovery and Validation of Preeclampsia-Associated Biomarkers. Methods Mol. Biol. 2019, 1959, 39-50. [CrossRef] [PubMed]

78. Liangsupree, T.; Multia, E.; Riekkola, M.-L. Modern Isolation and Separation Techniques for Extracellular Vesicles. J. Chromatogr. A 2021, 1636, 461773. [CrossRef]

79. Sidhom, K.; Obi, P.O.; Saleem, A. A Review of Exosomal Isolation Methods: Is Size Exclusion Chromatography the Best Option? Int. J. Mol. Sci. 2020, 21, 6466. [CrossRef]

80. Gaspar, L.S.; Santana, M.M.; Henriques, C.; Pinto, M.M.; Ribeiro-Rodrigues, T.M.; Girão, H.; Nobre, R.J.; Pereira de Almeida, L. Simple and Fast SEC-Based Protocol to Isolate Human Plasma-Derived Extracellular Vesicles for Transcriptional Research. Mol. Ther. Methods Clin. Dev. 2020, 18, 723-737. [CrossRef]

81. Van Deun, J.; Mestdagh, P.; Sormunen, R.; Cocquyt, V.; Vermaelen, K.; Vandesompele, J.; Bracke, M.; De Wever, O.; Hendrix, A. The Impact of Disparate Isolation Methods for Extracellular Vesicles on Downstream RNA Profiling. J. Extracell. Vesicles 2014, 3. [CrossRef]

82. Zhang, H.; Lyden, D. Asymmetric-Flow Field-Flow Fractionation Technology for Exomere and Small Extracellular Vesicle Separation and Characterization. Nat. Protoc. 2019, 14, 1027-1053. [CrossRef]

83. Van Deun, J.; Jo, A.; Li, H.; Lin, H.-Y.; Weissleder, R.; Im, H.; Lee, H. Integrated Dual-Mode Chromatography to Enrich Extracellular Vesicles from Plasma. Adv. Biosyst. 2020, 4, 1900310. [CrossRef] [PubMed]

84. Le Boeuf, B.J.; Ortiz, C.L. Composition of Elephant Seal Milk. J. Mammal. 1977, 58, 683-685. [CrossRef]

85. Lindmark Månsson, H. Fatty Acids in Bovine Milk Fat. Food Nutr. Res. 2008, 52. [CrossRef]

86. Jenness, R. The Composition of Human Milk. Semin. Perinatol. 1979, 3, 225-239. [CrossRef]

87. Rahman, M.M.; Shimizu, K.; Yamauchi, M.; Takase, H.; Ugawa, S.; Okada, A.; Inoshima, Y. Acidification Effects on Isolation of Extracellular Vesicles from Bovine Milk. PLoS ONE 2019, 14, e0222613. [CrossRef]

88. Schey, K.L.; Luther, J.M.; Rose, K.L. Proteomics Characterization of Exosome Cargo. Methods 2015, 75-82. [CrossRef]

89. Hessvik, N.P.; Llorente, A. Current Knowledge on Exosome Biogenesis and Release. Cell. Mol. Life Sci. 2018, 75, 193-208. [CrossRef] [PubMed]

90. Raposo, G.; Stoorvogel, W. Extracellular Vesicles: Exosomes, Microvesicles, and Friends. J. Cell Biol. 2013, 200, 373-383. [CrossRef]

91. Qin, W.; Tsukasaki, Y.; Dasgupta, S.; Mukhopadhyay, N.; Ikebe, M.; Sauter, E.R. Biology of Human Tumors Exosomes in Human Breast Milk Promote EMT. Clin. Cancer Res. 2016, 22. [CrossRef] [PubMed]

92. Lukasik, A.; Brzozowska, I.; Zielenkiewicz, U.; Zielenkiewicz, P. Detection of Plant MiRNAs Abundance in Human Breast Milk. Int. J. Mol. Sci. 2018, 19, 37. [CrossRef] [PubMed]

93. Burkova, E.E.; Grigor'eva, A.E.; Bulgakov, D.V.; Dmitrenok, P.S.; Vlassov, V.V.; Ryabchikova, E.I.; Sedykh, S.E.; Nevinsky, G.A. Extra Purified Exosomes from Human Placenta Contain an Unpredictable Small Number of Different Major Proteins. Int. J. Mol. Sci. 2019, 20, 2434. [CrossRef] [PubMed]

94. Reinhardt, T.A.; Lippolis, J.D.; Nonnecke, B.J.; Sacco, R.E. Bovine Milk Exosome Proteome. J. Proteom. 2012, 75, 1486-1492. [CrossRef]

95. Wojtuszkiewicz, A.; Schuurhuis, G.J.; Kessler, F.L.; Piersma, S.R.; Knol, J.C.; Pham, T.V.; Jansen, G.; Musters, R.J.P.; Van Meerlo, J.; Assaraf, Y.G.; et al. Exosomes Secreted by Apoptosis-Resistant Acute Myeloid Leukemia (AML) Blasts Harbor Regulatory Network Proteins Potentially Involved in Antagonism of Apoptosis. Mol. Cell. Proteom. 2016, 15, 1281-1298. [CrossRef]

96. Laganowsky, A.; Reading, E.; Hopper, J.T.S.; Robinson, C.V. Mass Spectrometry of Intact Membrane Protein Complexes. Nat. Protoc. 2013, 8, 639-651. [CrossRef]

97. Leon, I.R.; Schwammle, V.; Jensen, O.N.; Sprenger, R.R. Quantitative Assessment of In-Solution Digestion Efficiency Identifies Optimal Protocols for Unbiased Protein Analysis. Mol. Cell. Proteom. 2013, 12, 2992-3005. [CrossRef]

98. Loo, R.R.O.; Dales, N.; Andrews, P.C. Surfactant Effects on Protein Structure Examined by Electrospray Ionization Mass Spectrometry. Protein Sci. 1994, 3, 1975-1983. [CrossRef] [PubMed]

99. Zhang, N.; Li, L. Effects of Common Surfactants on Protein Digestion and Matrix-Assisted Laser Desorption/Ionization Mass Spectrometric Analysis of the Digested Peptides Using Two-Layer Sample Preparation. Rapid Commun. Mass Spectrom. 2004, 18, 889-896. [CrossRef] [PubMed]

100. Hustoft, H.K.; Malerod, H.; Wilson, S.R.; Reubsaet, L.; Lundanes, E.; Greibrokk, T. A Critical Review of Trypsin Digestion for LC-MS Based Proteomics. Integr. Proteom. 2012, 73, 73-82.

101. Meyer, J. Fast Proteome Identification and Quantification from Data-Dependent Acquisition-Tandem Mass Spectrometry (DDA MS/MS) Using Free Software Tools. Methods Protoc. 2019, 2, 8. [CrossRef] 
102. Tu, C.; Li, J.; Shen, S.; Sheng, Q.; Shyr, Y.; Qu, J. Performance Investigation of Proteomic Identification by HCD/CID Fragmentations in Combination with High/Low-Resolution Detectors on a Tribrid, High-Field Orbitrap Instrument. PLoS ONE 2016, 11, e0160160. [CrossRef] [PubMed]

103. Andrews, G.L.; Simons, B.L.; Young, J.B.; Hawkridge, A.M.; Muddiman, D.C. Performance Characteristics of a New Hybrid Quadrupole Time-of-Flight Tandem Mass Spectrometer (TripleTOF 5600). Anal. Chem. 2011, 83, 5442-5446. [CrossRef]

104. Li, J.; He, X.; Deng, Y.; Yang, C. An Update on Isolation Methods for Proteomic Studies of Extracellular Vesicles in Biofluids. Molecules 2019, 24, 3516. [CrossRef]

105. He, B.; Shi, J.; Wang, X.; Jiang, H.; Zhu, H.J. Label-Free Absolute Protein Quantification with Data-Independent Acquisition. J. Proteom. 2019, 200, 51-59. [CrossRef] [PubMed]

106. Law, K.P.; Lim, Y.P. Recent Advances in Mass Spectrometry: Data Independent Analysis and Hyper Reaction Monitoring. Expert Rev. Proteom. 2013, 551-566. [CrossRef] [PubMed]

107. Whitman, J.D.; Lynch, K.L. Optimization and Comparison of Information-Dependent Acquisition (IDA) to Sequential Window Acquisition of All Theoretical Fragment Ion Spectra (SWATH) for High-Resolution Mass Spectrometry in Clinical Toxicology. Clin. Chem. 2019. [CrossRef]

108. Ludwig, C.; Gillet, L.; Rosenberger, G.; Amon, S.; Collins, B.C.; Aebersold, R. Data-independent Acquisition-based SWATH-MS for Quantitative Proteomics: A Tutorial. Mol. Syst. Biol. 2018, 14. [CrossRef] [PubMed]

109. Chutipongtanate, S.; Greis, K.D. Multiplex Biomarker Screening Assay for Urinary Extracellular Vesicles Study: A Targeted Label-Free Proteomic Approach. Sci. Rep. 2018, 8. [CrossRef]

110. Moon, P.G.; Lee, J.E.; You, S.; Kim, T.K.; Cho, J.H.; Kim, I.S.; Kwon, T.H.; Kim, C.D.; Park, S.H.; Hwang, D.; et al. Proteomic Analysis of Urinary Exosomes from Patients of Early IgA Nephropathy and Thin Basement Membrane Nephropathy. Proteomics 2011, 11, 2459-2475. [CrossRef]

111. GOrilla. Available online: http:/ / cbl-gorilla.cs.technion.ac.il/ (accessed on 1 June 2021).

112. REVIGO. Available online: http:/ / revigo.irb.hr/ (accessed on 1 June 2021).

113. ExoCarta. Available online: http:/ / www.exocarta.org/ (accessed on 1 June 2021).

114. Vesiclepedia. Available online: http://microvesicles.org/ (accessed on 1 June 2021).

115. EVpedia. Available online: https://exosome-rna.com/tag/evpedia/ (accessed on 1 June 2021).

116. Kim, D.K.; Kang, B.; Kim, O.Y.; Choi, D.S.; Lee, J.; Kim, S.R.; Go, G.; Yoon, Y.J.; Kim, J.H.; Jang, S.C.; et al. EVpedia: An Integrated Database of High-Throughput Data for Systemic Analyses of Extracellular Vesicles. J. Extracell. Vesicles 2013, 2. [CrossRef] [PubMed]

117. Mathivanan, S.; Fahner, C.J.; Reid, G.E.; Simpson, R.J. ExoCarta 2012: Database of Exosomal Proteins, RNA and Lipids. Nucleic Acids Res. 2012, 40. [CrossRef]

118. Kalra, H.; Simpson, R.J.; Ji, H.; Aikawa, E.; Altevogt, P.; Askenase, P.; Bond, V.C.; Borràs, F.E.; Breakefield, X.; Budnik, V.; et al. Vesiclepedia: A Compendium for Extracellular Vesicles with Continuous Community Annotation. PLoS Biol. 2012, 10, e1001450. [CrossRef] [PubMed]

119. Doncheva, N.T.; Morris, J.H.; Gorodkin, J.; Jensen, L.J. Cytoscape StringApp: Network Analysis and Visualization of Proteomics Data. J. Proteome Res. 2019, 18, 623-632. [CrossRef] [PubMed]

120. Reimand, J.; Isserlin, R.; Voisin, V.; Kucera, M.; Tannus-Lopes, C.; Rostamianfar, A.; Wadi, L.; Meyer, M.; Wong, J.; Xu, C.; et al. Pathway Enrichment Analysis and Visualization of Omics Data Using g:Profiler, GSEA, Cytoscape and EnrichmentMap. Nat. Protoc. 2019, 14, 482-517. [CrossRef] [PubMed]

121. Pathan, M.; Keerthikumar, S.; Chisanga, D.; Alessandro, R.; Ang, C.-S.; Askenase, P.; Batagov, A.O.; Benito-Martin, A.; Camussi, G.; Clayton, A.; et al. A Novel Community Driven Software for Functional Enrichment Analysis of Extracellular Vesicles Data. J. Extracell. Vesicles 2017, 6, 1321455. [CrossRef] [PubMed] 